\title{
The inheritance of quantitative traits in Brassica napus ssp. rapifera(swedes): augmented triple test cross analysis of yield
}

\author{
L. D. RAMSAY, J. E. BRADSHAW† \& M. J. KEARSEY* \\ School of Biological Sciences, The University of Birmingham, Edgbaston, Birmingham B15 2TT and +Scottish Crop \\ Research Institute, Invergowrie, Dundee DD2 5DA, U.K.
}

\begin{abstract}
Two augmented triple test crosses were produced from inbred lines of swede (Brassica napus ssp. rapifera L.) and assessed in field trials at Dundee in 1988 and 1989, respectively. The first cross was between lines derived from cvs. Criffel and Marian and the second between the same Criffel line and one from Bangholm Wilby. The genetic architectures of the two components of dry weight yield were clearly different. Dry-matter percentage was mainly under the control of additive genetical variation whereas fresh weight yield was under the control of additive and dominance variation. Although there was unidirectional dominance (positive $[h]$ ) for high yield, the dominance ratio was less than unity in both crosses. Dry weight yield was also under the control of genes showing both additive and dominance variation. In both crosses $[h]$ was larger than $[d]$ and the $F_{1}$ outyielded the better parent by 14 and 12 per cent, respectively. The dominance ratio was less than unity, being 0.50 and 0.94 respectively. There was no evidence of overdominance. Whilst epistasis was not a major feature of the genetic architecture of dry matter yield and its components, there were large and unexpected reciprocal differences, particularly for fresh and dry weight yield in all TTC generations and the $F_{3}$ of the first cross. These require further investigation. Finally it was concluded that it should be possible to produce inbred cultivars of swede which outyield $F_{1}$ hybrids in a modest sized breeding programme because 12 and 2 per cent, respectively, of the recombinant inbred lines from the two crosses were predicted to outyield the $F_{1}$.
\end{abstract}

Keywords: Brassica napus, dry-matter yield, heterosis, swede, triple test cross.

\section{Introduction}

Since the early 1800 s the swede (Brassica napus ssp. rapifera L.) has been grown in the U.K. as a winter forage crop for cattle and sheep (McNaughton \& Thow, 1972). During the 19th century many new strains and varieties were produced by visual selection of attractive looking bulbs which were seeded in isolation from other multiplications. Between 1900 and 1930 the chemical composition of swedes was determined with a view to improving their feeding value but opinions differed over the relationship between chemical composition and feeding value (Bradshaw \& Griffiths, 1990). In Scotland, Lauder (1926, 1927) and Lauder \& Hendrick (1929) concluded that the swede with the highest dry-matter yield per acre was the most profitable one to grow and this became the main selection criterion in the swede

\footnotetext{
*Correspondence.
}

breeding programme at the Scottish Crop Research Institute (SCRI).

Although the swede is insect-pollinated, Davey (1938) showed that it is usually self-fertile and that inbreeding depression is mild. He produced uniform lines from variable commercial cultivars by a number of generations of natural selfing in pollen-proof bags but he did not consider the best lines to be sufficiently superior or distinct enough from their parent cultivars for release as new cultivars. He therefore decided to combine desirable characteristics from different cultivars, strains and pure lines through hybridizations, followed by bag-selfing and selection for a number of generations to produce true-breeding lines (Davey, 1941). This pedigree method which he developed has remained in use at SCRI with, for example, the cultivars Angus and Melfort coming from crosses made in 1967 (Munro, 1982).

In the 1930s Davey (1937) appreciated the vigour of the $F_{1}$ hybrid generation but at that time there was no way of producing large quantities of $F_{1}$ seed to exploit 
this heterosis in hybrid cultivars. Later Davey (1957) suggested using self-incompatibility for $F_{1}$ hybrid production but it was Gowers (1975) who developed methods of doing this, methods which he considered preferable to the use of cytoplasmic male sterility.

As $F_{1}$ hybrid swede cultivars can now be produced as readily as inbred cultivars, Bradshaw (1988) considered their relative merit and concluded that this depends on their relative performance, which in turn depends mainly on the magnitude and genetical basis of heterosis for dry-matter yield. McNaughton \& Munro (1972) and Gowers (1974) found that the drymatter yield of the $F_{1}$ could exceed the better parent by as much as 26 and 29 per cent, respectively. More recently, Ramsay (1991) found that, in a diallel set of crosses, 11 out of $55 \mathrm{~F}_{1}$ s outyielded their better parent by more than 20 per cent. Included among the 11 were the four highest yielding $F_{1} s$. However, it was not possible to determine the genetical basis of heterosis from this diallel, as a simple additive-dominance model with independence of the genes in action and in distribution failed to provide an adequate description of the data. Therefore two heterotic crosses were chosen for a more detailed study of heterosis using the biometrical genetical methods reviewed by Jinks (1983). One parent of each cross was a low dry-matter content $(\mathrm{DM} \%)$ line whilst the other parent was a low and a high line, respectively. The methods used included triple test crosses (Kearsey \& Jinks, 1968) augmented with the basic generations and $\mathrm{F}_{3} \mathrm{~S}$.

\section{Materials and methods}

\section{Inbred lines}

The two heterotic crosses chosen involved three inbred lines derived from commercial cultivars by selfing for five generations. BWc4hca (line B) was selected from cv. Bangholm Wilby for very high $\mathrm{DM} \%$. CRdagaa (line C) and MNcccaa (line M) were selected primarily for high dry-matter yield (DWT) from cvs. Criffel and Marian, respectively. The heterotic crosses were between $\mathrm{C}$ and $\mathrm{B}$, and $\mathrm{C}$ and $\mathrm{M}$.

\section{Pollinations}

Plants for pollination were raised from seed sown at the end of October and vernalized from mid-December to mid-March in a frost-free glasshouse. Pollinations were made from late April to the end of May at a minimum temperature of $12^{\circ} \mathrm{C}$ in an insect-proof glasshouse. As an additional precaution, the inflorescences were protected with Glassine bags for 2 weeks after pollination. Both selfing and crossing were carried out at the bud stage following emasculation.

\section{Augmented triple test cross 1 (TTC1)}

The initial reciprocal crosses between $\mathrm{C}$ and $\mathrm{M}$ were made in 1985 and seed of the Basic Generations $\left(\mathrm{BG}=\mathrm{P}_{1}, \mathrm{P}_{2}, \mathrm{~F}_{1}, \mathrm{~F}_{2}, \mathrm{~B}_{1}\right.$ and $\mathrm{B}_{2}$ ) was produced in 1986 and included all reciprocals. Seeds of the $\mathrm{F}_{3}$ and Triple Test Cross generations $\left(\mathrm{TTC}=\mathrm{L}_{1}, \mathrm{~L}_{2}\right.$ and $\mathrm{L}_{3}$ ) were produced in 1987 from $30 \mathrm{~F}_{2}$ plants which were used only as female parents for the TTC, $15 \mathrm{~F}_{2}$ plants from each of the two reciprocal $F_{1} s$.

\section{Augmented triple test cross 2 (TTC2)}

The reciprocal crosses between $\mathrm{C}$ and $\mathrm{B}$ were made in 1986 and the $F_{1} s$ were selfed in 1987. Seeds of the BG, $\mathrm{F}_{3}$ and TTC generations were produced in 1988 . Thirty $F_{2}$ plants were selfed and used both as male and female parents of the TTC families. There were again $15 \mathrm{~F}_{2}$ plants from each of the two reciprocal $F_{1} \mathrm{~s}$.

\section{Trial design and layout}

Augmented TTCs 1 and 2 were assessed in field trails at Invergowrie, Dundee in 1988 and 1989, respectively. Randomized complete block designs with four replicates were used. In the 1988 trial each replicate comprised 144 plots: $2 \mathrm{P}_{1}, 2 \mathrm{P}_{2}, 4 \mathrm{~F}_{1}, 8 \mathrm{~F}_{2}, 4 \mathrm{~B}_{1}, 4 \mathrm{~B}_{2}$ and one each of the $30 \mathrm{~F}_{3}$ and 90 TTC families. In 1989 there were 260 plots: $3 \mathrm{P}_{1}, 3 \mathrm{P}_{2}, 6 \mathrm{~F}_{1}, 16 \mathrm{~F}_{2}, 8 \mathrm{~B}_{1}$, $8 \mathrm{~B}_{2}$ and one each of the $30 \mathrm{~F}_{3}$ and 180 TTC families, plus one each of 6 extra $F_{3}$ families to make a convenient total.

A field plot comprised three rows each of five plants, plus a guard plant on either end. Rows were $50 \mathrm{~cm}$ apart and plants in rows were spaced $20 \mathrm{~cm}$ apart. Each replicate was surrounded with a double row of guards. Cultivars Marian and Melfort were used as guards in 1988 and 1989, respectively.

Plants for the field trails were raised from seed germinated on moist filter paper in petri dishes placed in an incubator at $18^{\circ} \mathrm{C}$ for 2 days. To ensure 15 plants for each field plot, 20 germinated seeds were sown into PlantPaks filled with UC compost. There was one seed per $40 \times 30 \times 50 \mathrm{~mm}$ cell. The PlantPaks were arranged in field plot order in an unheated glasshouse and surrounded with guards. Replicates 1 and 2, and 3 and 4 , of the 1988 trial were sown on 11 and 18 May, respectively. They were planted in the field on $6,7,13$ and 14 June respectively. The four replicates of the 1989 trial were sown on 10,11,17 and 18 May and planted on 5, 6, 12 and 13 June. 


\section{Cultural details}

Fertilizer was applied to the trial areas before planting to supply $102 \mathrm{~kg} / \mathrm{ha}$ each of $\mathrm{N}, \mathrm{P}_{2} \mathrm{O}_{5}$ and $\mathrm{K}_{2} \mathrm{O}$ and also to prevent boron deficiency.

Herbicides were used for weed control. Trifluralin was incorporated into the soil before planting in both years. In 1989 paraquat was also applied before planting and a mixture of chlorthal-dimethyl and propachlor was applied immediately after planting.

Cabbage root fly was controlled in 1988 by an application of carbofuran granules after planting, on 24 June; and in 1989 by chlorfenvinphos granules applied before planting on 2 June. In 1989 it was also necessary to apply lindane on 4 July to control aphids and benomyl on 22 August to control powdery mildew.

Overhead irrigation was used to aid establishment of the 1988 trial and the 1989 trial was watered twice during the dry summer, from 19 to 21 July and again from 2 to 3 August. Both trials were netted from planting until 25 and 19 July, respectively, to prevent bird damage.

\section{Harvest}

In 1988 the centre rows of all BG plots in replicates 1 to 4 were lifted from 31 October to 3 November. The five bulbs from each row were trimmed and weighed. Thin segments were cut from each bulb and oven-dried at $80^{\circ} \mathrm{C}$ for $24 \mathrm{~h}$ to determine the dry-matter percentage $(\mathrm{DM} \%)$ of each bulb. This was to aid comparison with a trial of the $\mathrm{BG}$ material involving randomized single plants. For the plots of $F_{3}$ and TTC families, a diagonal core was taken from each of the five bulbs in the centre row, and the outer skin removed with a knife before drying at $80^{\circ} \mathrm{C}$ for $24 \mathrm{~h}$. Replicates 1 and 2 were cored on 7 November, and replicates 3 and 4 on 8 November. The TTC plots, $F_{3}$ plots and the remaining rows of the BG plots in replicates 1 and 2 were lifted and trimmed on 9 November, followed by those in replicates 3 and 4 on 11 November. The weight of each row of five plants was recorded.

The harvest of the 1989 trial was simpler. Five cores were taken from the centre row of each plot and ovendried at $80^{\circ} \mathrm{C}$ for $24 \mathrm{~h}$ to determine $\mathrm{DM} \%$. Replicates 1 and 2 were cored on 30 and 31 October, respectively, and replicates 3 and 4 on 13 November. Then all of the plants in each plot were lifted and trimmed and fresh weight (FWT) yield was recorded on a plot rather than a row basis. Replicates 1 and 2 were scored on 6 and 7 November, respectively, and replicates 3 and 4 on 20 November.

\section{Analysis of data}

A range of genetical models was fitted to the generation means by the method of weighted least squares (Cavalli, 1952; Mather \& Jinks, 1982). The weights were the reciprocals of the variance of family means and were derived from the between rows, plots and replicates variances. The simplest model contained parameter $m$, the mean of the inbred population which could be derived from the cross, and the most parameters considered were $m ;[d]$ (additive); $[h]$ (dominance); $[i],[j]$ and $[l]$ (epistatic); $[d m]$ and $[\mathrm{hm}]$ (maternal); $[c]$ (cytoplasmic with coefficient 1 or -1 ); and in $1988[x]$ to allow for differences between the BG (coefficient 1), and other generations (coefficient 0 ), as seed was produced in different years and they were handled differently at harvest. When reciprocals were pooled, $[\mathrm{dm}]$ and $[c]$ could not be separated. The criteria used for deciding upon the best model were that the model adequately explained the data, that all the parameters used in the model were significant and that adequate, simple additive-dominance models were accepted in preference to better fitting but more complex models. All parameters used in the best models were significant (normal deviate $>1.96$ ).

The data from the triple test crosses were analysed by the methods of Kearsey \& Jinks (1968) and Jinks \& Perkins $(1970)$, and the data from the $F_{3}$ generation by the procedure given in Jinks \& Pooni (1980). Blocks and families were regarded as random effects and the reciprocal differences as fixed effects. Inclusion of reciprocal differences in the expected mean squares allowed the removal of variation due to maternal and cytoplasmic effects which would otherwise have inflated the estimates of the additive genetic variance $(D)$. Four estimates of $D$ were calculated from the variance of $\mathrm{L}_{1}+\mathrm{L}_{2}+\mathrm{L}_{3}, \mathrm{~L}_{1}+\mathrm{L}_{2}, \mathrm{~L}_{3}$ and $\mathrm{F}_{3}$ families. $H$ (the dominance variance) was estimated from $\mathrm{L}_{1}-\mathrm{L}_{2}$ and $F$ (the covariance of $d$ and $h$ ) from the covariance of $\mathrm{L}_{1}+\mathrm{L}_{2}$ and $\mathrm{L}_{1}-\mathrm{L}_{2}$ as described by Jinks et al. (1969). The non-heritable variance between plots $\left(E_{\text {plot }}\right)$ was estimated from the parents and $F_{1}$ and a measure of narrow heritability $\left(h_{n}^{2}\right)$ was calculated using the above variance estimates, with $h_{n}^{2}=\frac{1}{2} D /$ $\left(\frac{1}{2} D+\frac{1}{4} H+E_{\text {plot }}\right)$.

The properties of the inbred lines extractable from the crosses by single seed descent were predicted by the method of Jinks \& Pooni (1976) and Pooni et al. (1977), and Jinks \& Pooni (1980). The predictions were based on the $D$ estimates from the TTC and the relevant parameters from the best model fitted to the generation means, and also from estimates of $D$ and $m$ from the between $F_{3}$ family variance and $F_{3}$ generation mean, respectively. The $D$ estimate from the TTC was taken from $\mathrm{L}_{1}+\mathrm{L}_{2}$ or $\mathrm{L}_{1}+\mathrm{L}_{2}+\mathrm{L}_{3}$, depending on 
whether their relative size, together with that from $\mathrm{L}_{3}$, indicated any epistasis to be predominantly duplicate or complementary, respectively (Pooni \& Jinks, 1979).

\section{Results}

\section{Generation means and genetical models for $C \times M$, $M \times C$}

Initially reciprocals were pooled to give the 10 generation means shown in Table 1 . There was better-parent heterosis for FWT (21 per cent) and DWT (14 per cent) yield, but not for $\mathrm{DM} \%$. The best fitting genetical models are given in Table 2. The models for DM $\%$ and DWT yield were adequate, and the one for FWT yield almost adequate $(P=0.03)$. It can be seen that the better-parent heterosis for FWT and DWT yield resulted from $[h]>([d]+[i])$. For all three traits, parameter $[x]$ was required. Seed was produced in different years and it was handled differently at harvest.

When the reciprocals were examined large differences were found for FWT and DWT yields in all TTC and $\mathrm{F}_{3}$ generations $(P<0.001)$. The $\mathrm{MC}$ families were on average much lower yielding than the $\mathrm{CM}$ families: 74.54 vs. $97.12 \mathrm{t} /$ ha for FWT yield and 7.31 vs. 9.63 $\mathrm{t} /$ ha for DWT yield. There were also statistically significant reciprocal differences for DWT yield in $F_{2}$ $(P=0.05-0.01)$ and for $\mathrm{DM} \%$ in $\mathrm{L}_{1}(P<0.001)$ and $\mathrm{L}_{3}$ $(P=0.05-0.01)$.

The reciprocal differences made it difficult to fit simple genetical models to the complete set of 22 means for FWT and DWT yield and adequate models could not be found. The best models for both traits contained parameters $[l],[d m]$ and $[c]$ in addition to those shown in Table 2 . For both traits $[l]$ was negative, indicating duplicate epistasis; $[c]$ was negative indicating that Marian cytoplasm reduced yields; and $[\mathrm{dm}]$ was positive indicating that Marian as maternal parent

Table 1 Generation means for $\mathrm{C} \times \mathrm{M}, \mathrm{M} \times \mathrm{C}$ (mean of reciprocals)

\begin{tabular}{lrrr}
\hline & FWT (t/ha) & DM $\%$ & DWT (t/ha) \\
\hline $\mathrm{P}_{1}(\mathrm{M})$ & 88.83 & 10.74 & 9.54 \\
$\mathrm{P}_{2}(\mathrm{C})$ & 86.17 & 10.03 & 8.63 \\
$\mathrm{~F}_{1}$ & 107.16 & 10.17 & 10.92 \\
$\mathrm{~F}_{2}$ & 92.73 & 10.23 & 9.48 \\
$\mathrm{~B}_{1}$ & 101.79 & 10.36 & 10.54 \\
$\mathrm{~B}_{2}$ & 94.58 & 10.11 & 9.52 \\
$\mathrm{~F}_{3}$ & 72.66 & 9.82 & 7.13 \\
$\mathrm{~L}_{1}$ & 94.25 & 9.96 & 9.39 \\
$\mathrm{~L}_{2}$ & 87.03 & 9.81 & 8.53 \\
$\mathrm{~L}_{3}$ & 89.35 & 9.89 & 8.83 \\
\hline
\end{tabular}

improved yield. In contrast, an $m,[d],[x]$ model was again adequate for $\mathrm{DM} \%$ and the estimates were similar to those given in Table 2.

\section{Parameters from TTC and $F_{3}$ generations for $C \times M$, $M \times C$}

Analyses of variance of $\mathrm{L}_{1}+\mathrm{L}_{2}+\mathrm{L}_{3}, \mathrm{~L}_{1}+\mathrm{L}_{2}, \mathrm{~L}_{3}$ and $\mathrm{F}_{3}$ all provided evidence of statistically significant $(P=0.01-0.001)$ additive genetical variance $(D)$ for all three traits. Analysis of variance of $\mathrm{L}_{1}-\mathrm{L}_{2}$ provided evidence of statistically significant dominance variation $(H)$ for FWT and DWT yield $(P=0.01-0.001)$, but not for $\mathrm{DM} \%$. For all three traits there was no evidence of epistasis from the analysis of variance of $\mathrm{L}_{1}+\mathrm{L}_{2}-2 \mathrm{~L}_{3}$.

The estimates of parameters derived from the TTC and $F_{3}$ generations are shown in Table 3 . The relative sizes of $D\left(\mathrm{~L}_{1}+\mathrm{L}_{2}\right)$ and $H\left(\mathrm{~L}_{1}-\mathrm{L}_{2}\right)$ meant that the dominance ratios were less than unity for all three traits and were close to a half, $D$ being significantly larger

Table 2 Estimates of parameters for generation means $\mathrm{C} \times \mathrm{M}, \mathrm{M} \times \mathrm{C}$ (mean of reciprocals)

\begin{tabular}{lccc}
\hline & FWT (t/ha) & DM $\%$ & DWT (t/ha) \\
\hline$m$ & $70.84 \pm 4.24$ & $9.84 \pm 0.04$ & $7.00 \pm 0.30$ \\
{$[d]$} & - & $0.32 \pm 0.06$ & $0.69 \pm 0.20$ \\
{$[h]$} & $36.95 \pm 7.51$ & - & $3.32 \pm 0.49$ \\
{$[i]$} & $11.67 \pm 5.19$ & - & $1.24 \pm 0.43$ \\
{$[j]$} & $14.64 \pm 5.47$ & - & - \\
{$[l]$} & - & - & - \\
{$[x]$} & $4.86 \pm 2.18$ & $0.49 \pm 0.06$ & $0.78 \pm 0.18$ \\
d.f. & 5 & 7 & 5 \\
$\chi_{\text {d.f. }}^{2}$ & 12.12 & 5.46 & 8.38 \\
$\chi_{9}^{2}$ for $m$ & $(P=0.03)$ & $(P=0.60)$ & $(P=0.14)$ \\
\hline
\end{tabular}

Table 3 Estimates of parameters derived from TTC and $\mathrm{F}_{3}$ generations for $\mathrm{C} \times \mathrm{M}, \mathrm{M} \times \mathrm{C}$ (reciprocal differences removed)

\begin{tabular}{lccc}
\hline & FWT (t/ha) & DM\% & DWT (t/ha) \\
\hline$D\left(\mathrm{~L}_{1}+\mathrm{L}_{2}+\mathrm{L}_{3}\right)$ & 642.18 & 0.299 & 6.987 \\
$D\left(\mathrm{~L}_{1}+\mathrm{L}_{2}\right)$ & 729.72 & 0.220 & 7.925 \\
$D\left(\mathrm{~L}_{3}\right)$ & 544.33 & 0.515 & 5.236 \\
$D\left(\mathrm{~F}_{3}\right)$ & 691.28 & 0.417 & 6.760 \\
$H\left(\mathrm{~L}_{1}-\mathrm{L}_{2}\right)$ & 263.37 & $0.068 \mathrm{NS}$ & 1.971 \\
$(H / D)^{1 / 2}$ & 0.601 & 0.556 & 0.499 \\
$F$ & $-103.99 \mathrm{NS}$ & - & $-0.769 \mathrm{NS}$ \\
$E_{\text {plot }}$ & 112.0 & 0.054 & 1.041 \\
$h_{n}^{2}$ & 0.672 & 0.609 & 0.721 \\
\hline \multicolumn{5}{r}{}
\end{tabular}


than $H$ for FWT and DWT $(P=0.05-0.01$ and $P<0.01$, respectively). $E_{\text {plot }}$ was less than $H$ for all three traits. The large reciprocal differences for FWT and DWT yield had been removed from the analysis.

\section{Properties of recombinant inbred lines extractable from $C \times M, M \times C$}

The univariate predictions of the proportions of inbred lines expected to exceed the better parent (line $\mathrm{M}$ ) and $F_{1}$ are given in Table 4 . They were made from the relevant parameters in Tables 2 and 3. For DM\%, $\mathrm{L}_{1}+\mathrm{L}_{2}+\mathrm{L}_{3}$ was used in preference to $\mathrm{L}_{1}+\mathrm{L}_{2}$. It can be seen that the predicted proportion of transgressive segregants was high, with 32 and 25 per cent (TTC) exceeding the better parent for FWT and DWT yield respectively. Furthermore, for FWT and DWT yield where there was better-parent heterosis, 7 and 12 per cent, respectively, were expected to exceed the $F_{1}$. It can also be seen that the predictions using the $F_{3}$ generation were similar though less than those based on the TTC generations.

\section{Generation means and genetical models for $C \times B$, $B \times C$}

Initially reciprocals were pooled to give the 10 generation means shown in Table 5. There was better-parent heterosis for FWT ( 3 per cent) and DWT ( 12 per cent) yield, but not for $\mathrm{DM} \%$. The best fitting genetical models are given in Table 6. The models for FWT yield and DM\% were adequate, and the one for DWT yield almost adequate $(P=0.04)$. It can be seen that the better-parent heterosis for FWT and DWT yield resulted from $[h]>[d]$.

When the reciprocals were examined, some differences were found for all three traits but not to the same extent as for $\mathrm{C}$ by $\mathrm{M}$.

The reciprocal differences made it difficult to fit simple genetical models to the complete set of 28

Table 4 Proportions of inbred lines from $\mathrm{C} \times \mathrm{M}, \mathrm{M} \times \mathrm{C}$ expected to exceed better parents and $\mathrm{F}_{1}$ using estimates from TTC and $\mathrm{F}_{3}$

\begin{tabular}{lccc}
\hline & FWT & DM\% & DWT \\
\hline Better parent & $\mathrm{M}$ & $\mathrm{M}$ & $\mathrm{M}$ \\
$>\mathrm{P}_{1}$ TTC & 0.323 & 0.277 & 0.247 \\
$>\mathrm{P}_{1} \mathrm{~F}_{3}$ & 0.209 & 0.079 & 0.177 \\
$>\mathrm{F}_{1}$ TTC & 0.072 & 0.500 & 0.120 \\
$>\mathrm{F}_{1} \mathrm{~F}_{3}$ & 0.042 & 0.297 & 0.072 \\
\hline
\end{tabular}

means. Adequate models could not be found for FWT and DWT yield. The best models for FWT yield, $\mathrm{DM} \%$ and DWT yield contained parameters $[\mathrm{dm}]$, $[\mathrm{hm}]$ and $[\mathrm{c}]$ in addition to those shown in Table 6 , and FWT yield also had $[j]$. However, the additional parameters did not greatly alter the values of the parameters shown in Table 6 .

\section{Parameters from TTC and $F_{3}$ generations for $C \times B$, $B \times C$}

Analyses of variance of $\mathrm{L}_{1}+\mathrm{L}_{2}+\mathrm{L}_{3}, \mathrm{~L}_{1}+\mathrm{L}_{2}, \mathrm{~L}_{3}$ and $\mathrm{F}_{3}$ all provided evidence of statistically significant $(P=0.01-0.001)$ additive genetical variation $(D)$ for all three traits. For FWT and DWT yield analyses of variance of $\mathrm{L}_{1}-\mathrm{L}_{2}$ and $\mathrm{L}_{1}+\mathrm{L}_{2}-2 \mathrm{~L}_{3}$ provided evidence of statistically significant dominance variation $(H) \quad(P=0.01-0.001)$ and $J / L$ epistatic variation $(P=0.05-0.01)$, respectively. The component of variation for epistasis was, however, small compared with those for $D$ and $H$. For $\mathrm{DM} \%$ there was no sta-

Table 5 Generation means for $\mathrm{C} \times \mathrm{B}, \mathrm{B} \times \mathrm{C}$ (mean of reciprocals)

\begin{tabular}{llll}
\hline & FWT $(\mathrm{t} / \mathrm{ha})$ & DM\% & DWT $(\mathrm{t} / \mathrm{ha})$ \\
\hline $\mathrm{C}$ & $72.61\left(\mathrm{P}_{1}\right)$ & 10.43 & $7.57\left(\mathrm{P}_{1}\right)$ \\
$\mathrm{B}$ & 38.44 & $14.19\left(\mathrm{P}_{1}\right)$ & 5.45 \\
$\mathrm{~F}_{1}$ & 75.03 & 11.30 & 8.47 \\
$\mathrm{~F}_{2}$ & 62.08 & 11.49 & 7.12 \\
$\mathrm{~B}_{1}$ & 65.19 & 12.69 & 6.96 \\
$\mathrm{~B}_{2}$ & 57.90 & 10.69 & 7.33 \\
$\mathrm{~F}_{3}$ & 56.22 & 11.97 & 6.67 \\
$\mathrm{~L}_{1}$ & 70.24 & 12.81 & 7.56 \\
$\mathrm{~L}_{2}$ & 56.40 & 10.78 & 7.20 \\
$\mathrm{~L}_{3}$ & 63.38 & 11.65 & 7.36 \\
\hline
\end{tabular}

Table 6 Estimates of parameters for generation means $\mathrm{C} \times \mathrm{B}, \mathrm{B} \times \mathrm{C}$ (mean of reciprocals)

\begin{tabular}{lccc}
\hline & FWT $(\mathrm{t} / \mathrm{ha})$ & DM\% & DWT $(\mathrm{t} / \mathrm{ha})$ \\
\hline$m$ & $52.25 \pm 1.05$ & $12.27 \pm 0.06$ & $6.22 \pm 0.11$ \\
{$[d]$} & $13.89 \pm 1.02$ & $1.92 \pm 0.05$ & $1.01 \pm 0.19$ \\
{$[h]$} & $22.20 \pm 1.93$ & $-1.03 \pm 0.10$ & $2.16 \pm 0.21$ \\
{$[i]$} & - & - & - \\
{$[j]$} & - & - & $-1.75 \pm 0.47$ \\
{$[l]$} & - & - & - \\
d.f. & 7 & 7 & 6 \\
$\chi_{\text {d.f. }}^{2}$ & 11.07 & 8.46 & 13.46 \\
$\chi_{9}^{2}$ for $m$ & $(P=0.14)$ & $(P=0.29)$ & $(P=0.04)$ \\
\hline & 397.53 & 1335.03 & 163.07 \\
\hline
\end{tabular}


tistically significant $H$ or $J / L$ variation, but the overall $\mathrm{L}_{1}+\mathrm{L}_{2}-2 \mathrm{~L}_{3}$ difference was significant $(P=0.01-0.001)$, thus providing evidence of $I$ type epistasis.

The estimates of parameters derived from the TTC and $\mathrm{F}_{3}$ generations are shown in Table 7 . The relative sizes of $D\left(\mathrm{~L}_{1}+\mathrm{L}_{2}\right)$ and $H\left(\mathrm{~L}_{1}-\mathrm{L}_{2}\right)$ meant that the dominance ratio was less than, but close to, unity for FWT and DWT yield, and close to zero for DM\%. $E_{\text {plot }}$ was less than $D$.

For all three traits the reciprocal differences had been removed from the analyses. For FWT and DWT yield they were due entirely to the difference between the reciprocal $F_{1} s$ whereas for $D M \%$ some variation was also due to the reciprocal pollinations used to produce the TTC families.

\section{Properties of recombinant inbred lines extractable from $C \times B, B \times C$}

The univariate predictions of the proportion of inbred lines expected to exceed the better parent and $F_{1}$ are given in Table 8 . For all three traits $\mathrm{L}_{1}+\mathrm{L}_{2}+\mathrm{L}_{3}$ were used in preference to $L_{1}+L_{2}$ as the estimates of $D$

Table 7 Estimates of parameters derived from TTC and $\mathrm{F}_{3}$ generations for $\mathrm{B} \times \mathrm{C}, \mathrm{C} \times \mathrm{B}$ (reciprocal differences removed)

\begin{tabular}{lccc}
\hline & FWT (t/ha) & DM\% & DWT (t/ha) \\
\hline$D\left(\mathrm{~L}_{1}+\mathrm{L}_{2}+\mathrm{L}_{3}\right)$ & 94.90 & 0.892 & 1.007 \\
$D\left(\mathrm{~L}_{1}+\mathrm{L}_{2}\right)$ & 104.64 & 0.790 & 1.205 \\
$D\left(\mathrm{~L}_{3}\right)$ & 123.80 & 0.901 & 1.377 \\
$D\left(\mathrm{~F}_{3}\right)$ & 91.20 & 0.731 & 1.044 \\
$H\left(\mathrm{~L}_{1}-\mathrm{L}_{2}\right)$ & 77.87 & 0.057 & 1.067 \\
$(H / D)^{1 / 2}$ & 0.863 & 0.269 & 0.941 \\
$F$ & $9.34 \mathrm{NS}$ & -0.132 & - \\
$E_{\text {plot }}$ & 58.31 & 0.130 & 0.710 \\
$h_{n}^{2}$ & 0.402 & 0.732 & 0.382 \\
\hline
\end{tabular}

Table 8 Proportions of inbred lines from $\mathrm{C} \times \mathrm{B}, \mathrm{B} \times \mathrm{C}$ expected to exceed better parents and $\mathrm{F}_{1}$ using estimates from TTC and $\mathrm{F}_{3}$

\begin{tabular}{lccc}
\hline & FWT & DM\% & DWT \\
\hline Better parent & C & B & C \\
$>\mathrm{P}_{1}$ TTC & 0.077 & 0.014 & 0.158 \\
$>\mathrm{P}_{1} \mathrm{~F}_{3}$ & 0.184 & 0.005 & 0.190 \\
$>\mathrm{F}_{1}$ TTC & 0.011 & 0.878 & 0.016 \\
$>\mathrm{F}_{1} \mathrm{~F}_{3}$ & 0.024 & 0.781 & 0.040 \\
\hline
\end{tabular}

showed some evidence of complementary epistasis. Parent $\mathrm{B}$ had a high $\mathrm{DM} \%$, so not surprisingly only a small proportion of segregants (1 per cent) was expected to exceed it. For DWT yield, however, 16 per cent were expected to exceed the better parent, with around 3 per cent outyielding the heterotic $F_{1}$. It can also be seen that the predictions using the $F_{3}$ generation were higher for FWT and DWT yield and lower for $\mathrm{DM} \%$ than those based on the TTC generations.

\section{Discussion}

The genetic architectures of the two components of DWT yield were clearly different. DM\% was mainly under the control of additive genetical variation, both when the low $\mathrm{DM} \%$ line from cv. Criffel was crossed to another fairly low $\mathrm{DM} \%$ line, and when it was crossed to a very high $\mathrm{DM} \%$ line. The $\mathrm{DM} \%$ of the $\mathrm{F}_{1}$ s lay between the mid-parent value and that of the low parent, but $[h]$ had a statistically significant negative value only in the second cross. In the $11 \times 11$ diallel of Ramsay (1991) the mean of the $F_{1}$ s was also less than the mean of the parents. Interestingly Davey (1954) reported that swedes selected at Corstorphine for their high yield had a low DM\%. In both crosses the dominance variance $(H)$ was small in size compared with the additive variance $(D)$, and in neither cross was it statistically significant. In the $11 \times 11$ diallel of Ramsey (1991) there was statistically significant non-additive variation, but it was small in size compared with the additive variation, as previously found in diallels by Denton \& Whittington $(1975,1976)$.

FWT yield was under the control of additive and dominance variation, both when the high FWT yield line from cv. Criffel was crossed to another high FWT yield line so that $[d]$ was not significant, and when it was crossed to a low FWT yield line. In both crosses $[h]$ had a large positive value indicative of unidirectional dominance for high yield and the $F_{1}$ outyielded the better parent. There was, however, more additive than dominance variation so that the dominance ratio was less than unity. Hence, in the first cross, the partially dominant genes for high yield were dispersed between the parents whereas in the second cross they were mainly but not entirely associated in the high yielding parent. Denton \& Whittington $(1975,1976)$, Grant et al. (1982) and Ramsay (1991) all reported both additive and non-additive variation for fresh weight yield in swede diallels, but were unable to perform such detailed analyses as reported here. Denton \& Whittington $(1975,1976)$ did, however, interpret their results as evidence of overdominance whilst Grant et al. (1982) concluded they were dealing with partial dominance and Ramsay (1991) concluded that 
a simple additive-dominance model failed to provide an adequate description of his data.

DWT yield, not surprisingly, was also under the control of both additive and dominance variation. In both cases $[h]$ was larger than $[d]$ and the $F_{1}$ outyielded the better parent. The levels of better-parent heterosis were 14 and 12 per cent, respectively, and were in the ranges reported by McNaughton \& Munro (1972) and Gowers (1974), namely 6-26 and 12-29 per cent, respectively. In the first cross there was four times more additive than dominance variation, giving a dominance ratio of a half, whereas in the second cross the variations were of the same order of magnitude and the dominance ratio was close to unity (0.94). The genetical basis of the heterosis in the first cross was therefore a dispersion of partially dominant genes in the parents, and in the second cross, a dispersion of dominant genes. There was no evidence of overdominance.

Epistasis affected the generation means in both crosses, and the variances in the second cross, but there was no consistent pattern. Epistasis does not, therefore, appear to be a major feature of the genetic architecture of dry-matter yield and its components in swedes.

In contrast, large and unexpected reciprocal differences occurred, particularly for FWT and DWT yield in all TTC and $F_{3}$ generations of the first cross. In neither cross did the inclusion of parameters for maternal and cytoplasmic effects allow adequate models to the generation means to be found for FWT and DWT yield. Hence it is not possible to offer a satisfactory explanation of these reciprocal differences, and futher investigation is clearly required. In the first cross part of the yield reduction was attributed to the Marian cytoplasm, so this is one possible line of investigation. Another approach will be to look into factors affecting seed size and quality to see if the way plants are grown for pollination and the way pollinations are performed could introduce reciprocal differences. A parameter $[x]$ was clearly required in the first cross to allow for differences between the basic and other generations where seed was produced in different years, although there were also differences in harvesting technique. However, reciprocal differences were still a feature of the second cross where all of the seed was produced in one glasshouse over a relatively short period of time.

The results from the two crosses have important implications for swede breeding. As there was no evidence of overdominance as a cause of the heterosis for dry-matter yield, it should be possible to produce inbred cultivars which outyield the $F_{1}$ hybrid. Furthermore, this should be possible in a modest sized breeding programme. The predictions for the two crosses were that around 25 and 16 per cent, respectively, of recombinant inbred lines were expected to outyield the better parent, with 12 and 2 per cent, respectively, outyielding the $F_{1}$.

There is, however, a need for more efficient inbreeding and selection procedures than those described by Bradshaw (1988), because in recent years little progress has been made in improving the yield of swedes. Cultivar Melfort, for example, has been on the National Institute of Agricultural Botany Recommended List since 1982 and is still the highest yielding cultivar. In a small breeding programme it would make sense to seek and concentrate the effort on high yielding heterotic crosses between parents which complement one another for other desirable traits. High yielding self-incompatible lines could be used to produce enough seed to select such $F_{1}$ s from replicated trails over sites and seasons; or in the absence of suitable self-incompatible lines, crosses could be selected at $F_{2}$. If reciprocal differences were found, the higher yielding reciprocal would be used. The means and variances of the $\mathrm{F}_{3}$ families derived from the selected heterotic crosses could then be used to predict their potential, and thus ensure that only the most promising crosses were advanced to $F_{4}$, and that enough lines were advanced to achieve the desired improvement in yield. There was, after all, reasonable agreement between the predictions from the TTC and those based on the $\mathrm{F}_{3}$ generation, despite the latter containing a small dominance component. The effects of interplot competition in early generation trials could be reduced by statistical modelling (Bradshaw, 1989), and more than one sowing date in the $\mathrm{F}_{5}$ generation might provide useful genotype $\times$ environment interaction information before deciding which lines to multiply as potential cultivars. Finally, it should be possible to use the genetical information from the two crosses in computer simulations of various inbreeding and selection schemes in order to choose the best scheme to use in practice.

\section{Acknowledgements}

We would like to thank Mrs Eva Bennett for technical assistance. The computing facilities of the University of Birmingham Computing Centre were made available for this project. L.D.R. was in receipt of a SERC CASE studentship.

\section{References}

BRADSHAW, J. E. 1988. The relative merits of lines versus hybrids in swedes (Brassica napus L. ssp. rapifera). In: Proc 7th Meeting of EUCARPIA Sec. Biometrics in Plant Breeding, Birmingham, pp. 47-57. 
BRADSHAW, J. E. 1989. Inter-plot competition in yield trials of swedes (Brassica napus ssp. rapifera L.). Euphytica, 42, 135-140.

BRADSHAW, J. E. AND GRIFFITHS, D. W. 1990. Sugar content of swedes for stock-feeding. J. Sci. Food Agric., 50, 167-172.

CAVALLI, L. I. 1952. An analysis of linkage in quantitative inheritance. In: Reeve, E. C. R. and Waddington, C. H. (eds) Quantitative Inheritance, pp. 135-144. HMSO, London.

DAVEY, v. McM. 1937. Root crops. Rep. Scott. Soc. for Research in Plant Breeding, 1937, 25-28.

DAVEY, v. McM. 1938. Root crops. Rep. Scott. Soc. for Research in Plant Breeding, 1938, 28-31.

DAVEY, v. McM. 1941. Root crops. Rep. Scott. Soc. for Research in Plant Breeding, 1941, 24-26.

DAVEY, v. McM. 1957. Root crops. Rep. Scott. Plant Breeding Sth, 1957, 18-24.

DENTON, O. A. AND WHITtington, w. J. 1975. The response of swede varieties and their hybrids to soil pH. J. Agric. Sci. Camb., 85, 395-401.

DENTON, O. A. AND whitTington, w. J. 1976. Genetic variation amongst swede varieties and their hybrids and their response to soil fertility. J. Agric. Sci. Camb., 87, 443-446.

GowERs, s. 1974. The production of $F_{1}$ hybrid swedes (Brassica napus ssp. rapifera) by the utilization of selfincompatibility. Euphytica, 23, 205-208.

Gowers, s. 1975. Methods of producing $F_{1}$ hybrid swedes (Brassica napus ssp. rapifera). Euphytica, 24, 537-541.

GRANT, I., HARNEY, P. M. AND CHRISTIE, B. R. 1982. Inheritance of yield and other quantitative characters in Brassica napus var. napobrassica. Can. J. Genet. Cytol., 24, 459--465.

JiNKs, J. L. 1983. Biometrical genetics of heterosis. In: Frankel, R. (ed.) Heterosis. Monographs on theoretical and applied genetics, Vol. 6, pp. 1-46. Springer, Berlin.

JINKS, J. L. AND PERKINS, J. M. 1970. A general method for the detection of additive, dominance and epistatic components of variation. III. $F_{2}$ and backcross populations. Heredity, 25, 419-429.
JINKS, J. L. AND POONI, H. S. 1976. Predicting the properties of recombinant lines derived by single seed descent. Heredity, 36, 253-266.

JINKS, J. L. AND POONI, H. S. 1990. Comparing predictions of mean performance and environmental sensitivity of recombinant inbred lines based upon $F_{3}$ and triple test cross families. Heredity, 45, 305-312.

JiNKS, J. L., PERKINS, J. M. AND BREESE, E. L. 1969. A general method of detecting additive, dominance and epistatic variation for metrical traits. II. Application to inbred lines. Heredity, 24, 45-47.

KEARSEY, M. J. AND JINKS, J. L. 1968. A general method of detecting additive, dominance and epistatic variation for metrical traits. I. Theory. Heredity, 23, 403-409.

LAuder, A. 1926. The composition of swedes. Scott. J. Agric., 9, 160-167.

LAUDER, A. 1927. The composition of swedes. Scott. J. Agric., 10, 428-433.

LAUDER, A. AND HENDRICK, J. 1929. The composition of swedes. Scott. J. Agric., 12, 310-312.

McNAUGHTON, I. H. AND MUNRO, I. K. 1972. Heterosis and its possible exploitation in swedes (Brassica napus L. ssp. rapifera). Euphytica, 21, 518-522.

McNAUGHTON, I. H. AND THOW, R. F. 1972. Swedes and turnips. Field Crop Abstracts, 25, 1-12.

MATHER, K. AND Jinks, J. L. 1982. Biometrical Genetics, 3rd edn. Chapman and Hall, London.

MUNRo, 1. K. 1982. New swede cultivars. Scott. Crop Research Institute Annual Report, 1982, 68.

POONI, H. S. AND JINKS, J. L. 1979. Sources and biases of the predictors of the properties of recombinant inbreds produced by single seed descent. Heredity, 42, 41-48.

POONI, H. S., JINKS, J. L. AND CORNISH, M. A. 1977. The causes and consequences of non-normality in predicting the properties of recombinant inbred lines. Heredity, 38, 329-338.

RAMSAY, L. D. 1991. Application of Biometrical Genetics to Swede Breeding. Ph. D. Thesis, University of Birmingham. 